\title{
1. INTRODUCTION AND EXPLANATORY NOTES, LEG 42B, DEEP SEA DRILLING PROJECT
}

\author{
David A. Ross, Woods Hole Oceanographic Institution, Woods Hole, Massachusetts \\ Yuri P. Neprochnov, USSR Academy of Sciences, Moscow, USSR \\ and \\ Peter R.Supko, National Research Institute for Oceanology, Stellenbosch, South Africa
}

\section{SCIENTIFIC OBJECTIVES AND RESULTS}

\section{Background}

The Black Sea is a large $\left(423,000 \mathrm{~km}^{2}\right)$, deep $(2,000 \mathrm{~m})$ semi-isolated marine basin situated between two Alpine mountain ranges, the Caucasus Mountains to the north and east and the Pontic Mountains to the south. The age of the Black Sea sedimentary basin is unknown, although it probably dates back to the middle or late Mesozoic and is thought to be a remnant of the ancient Tethys Sea which existed prior to the present cycle of plate movements which has resulted in the present configuration of the land masses and ocean basins. Geophysical studies have shown that the central Black Sea basin has a total crustal thickness of between 18 and $24 \mathrm{~km}$, including a sedimentary layer 8 to 16 $\mathrm{km}$ thick (see Neprochnov and Ross, this volume, for a discussion of the geophysical framework of the Black Sea).

The Black Sea is of extreme interest to oceanographers because of its near unique hydrologic, and as a result sedimentologic, regime. Although early in its history the Black Sea may have been connected to the Caspian Sea and perhaps other water bodies, it is now connected only to the Mediterranean Sea through the Bosporus, a narrow strait having a sill depth of only some 50 meters. The Black Sea, because of climatic conditions and drainage pattern, is an area of net excess of precipitation over evaporation; there is a surface outflow of fresher waters over the sill with only little bottom inflow of more dense saline Mediterranean water. There is thus virtually no oxygen resupply to the deep waters, causing the Black Sea to be the largest anoxic body of water in the world; from about 100 meters depth to the bottom at 2200 meters, the water contains hydrogen sulfide, deadly to all forms of life except anaerobic bacteria. Black Sea sediments accumulate at high rates because of the nearness of well-drained provenance areas and contain high levels of organic carbon because of the lack of biological activity at depth.

Extreme changes in the sedimentation regimes of the Black Sea occurred as a result of eustatic changes in sea level and the shallowness of the Bosporus sill. When sea level fell in response to Pleistocene glaciations, the Black Sea became disconnected from the Mediterranean and changed from marine to lacustrine conditions. For example, a number of studies (Degens and Ross, 1974, and references therein), based on piston core samples, has shown that lacustrine conditions prevailed during the last (Würmian or Wisconsin) glaciation; when sea level began to rise about 15,000 years ago, it slowly returned to marine conditions reaching its present state only about 3000 B.P.
Because of high sedimentation rates, we expected a greatly expanded Quaternary sedimentary sequence. Deepsea drilling and coring offered the unique chance to sample this sequence in detail and to work out a geological history of the Black Sea and its response to global eustatic changes in sea level. We also put heavy emphasis on geochemical studies, both with an active shipboard chemistry program and numerous later studies ashore. This was particularly true for the organic geochemistry program. An active heat flow program was also planned.

In general the main objectives of the drilling program in the Black Sea were:

1) To obtain as complete as possible a Quaternary lithostratigraphic and biostratigraphic section.

2) To detail the interactions between the Black Sea and the Mediterranean, especially glacio-eustatic sea level changes, periods of lacustrine sedimentation, and periods of stagnation, and to establish a paleoclimatic record.

3) To attempt to reach Neogene deposits.

4) To obtain information on the nature and history of the Black Sea depression.

5) To determine the age, composition, and significance of several strong acoustic reflectors.

6) To study organic diagenetic changes, including the formation of hydrocarbons and the degradation of amino acids, carbohydrates, and porphyrins, and to attempt to observe the beginning of catagenesis in the intermediate depth zone below 500 meters.

\section{Summary of Scientific Results}

Despite the fact that coring was nearly continuous and that the numerous shore-based studies of the Black Sea cores have been undertaken (see Table of Contents), we find that it is nearly impossible to construct an overall late Neogene-Pleistocene history of the Black Sea which is acceptable even to our own shipboard party, particularly with regard to stratigraphy and dating. A major reason for this difficulty is the severe shortage of definitive paleontological age markers. The sediments cored are all very young hence evolutionary lineages are few; rapidly fluctuating environmental conditions often were more effective in altering floral and faunal composition than were evolutionary factors, particularly true of the calcareous nannofossils. This group, most often the key fossil suite for biostratigraphic zonation of open marine sequences, was all but useless in the Black Sea. Diatoms and pollen and spores have been of some use in reconstruction of paleoenvironments and have been used for biostratigraphic correlation (Traverse, this volume; Schrader, this volume; Jouse' and Mukhina, this 
volume; Koreneva and Kartashova, this volume) and Traverse has used ratios of steppe (cold) to forest (warm) pollen assemblages to delineate a cyclical change from glacial to interglacial conditions, although exact correlation to classical glacial stratigraphies is still open to debate. Floral and faunal studies were also made more confusing by reworking and incorporation of older forms into younger sediments.

Different workers have used different time zonation schemes for explaining the lithologic units at the three drilled sites. There remain major differences of opinion among shipboard geologists who have tried to tie their sedimentary units to geologic facies interpretations and then to a stratigraphic correlation. These large and unresolved problems are discussed by Ross (Black Sea Stratigraphy, this volume). An attempt at synthesis (Ross, this volume) became so complex as to be impossible to abstract for presentation here; the reader is referred to the specific chapters authored by shipboard and shore-based investigators (particularly Part III and Part VI and to the summary chapter). We report below only the site-by-site major results.

The drill site locations are shown in Figure 1 and the operational statistics in Table 1.

\section{Site 379}

Site 379 , in the central portion of the Black Sea, was continuously cored to a subbottom depth of 624.5 meters.
Generally all the cores were gassy and in several instances sediment was forcibly extruded by gas pressure from the core barrel once the cores were on deck. Most recovered cores had void areas due to the expanding gas. Gas content was monitored on all cores, methane and $\mathrm{CO}_{2}$ being the most common gases with considerably smaller amounts of ethane. Butylanes and propane, probably from early diagenesis of organic matter, were detected in two cores in a few parts per million, but the methane/ethane ratio for these and all other cores clearly stayed within safety limits.

A total of nine sedimentary units was defined at Site 379 . These included two near-surface units sampled by piston coring from an earlier Atlantis II cruise. Terrigenous mud (Units 3,6, and 8), generally with turbidite sequences, was the most common lithology. Unit 4, a diatomaceous nannofossil mud, is, except for its diatoms and nannofossils, similar to Unit 3 . This fossil assemblage occurs again in Unit 7, a nannofossil diatomaceous marl. Unit 1 is nanno ooze composed primarily of Emiliania huxleyi. Sapropels (Units 2 and 5) of about $30 \mathrm{~cm}$ thickness were found in two instances.

Unit 9, a dolomitic mud rock, is especially interesting in that it has a rhythmic pattern consisting of an alternating sequence of dark clay, dolomite, and pyrite. The sequence, generally $3-6 \mathrm{~cm}$ thick, starts with a fine layer of pyrite (1-2 $\mathrm{mm}$ thick) at the bottom followed by dark clay grading upwards into a light clay. This clay layer is overlain by a

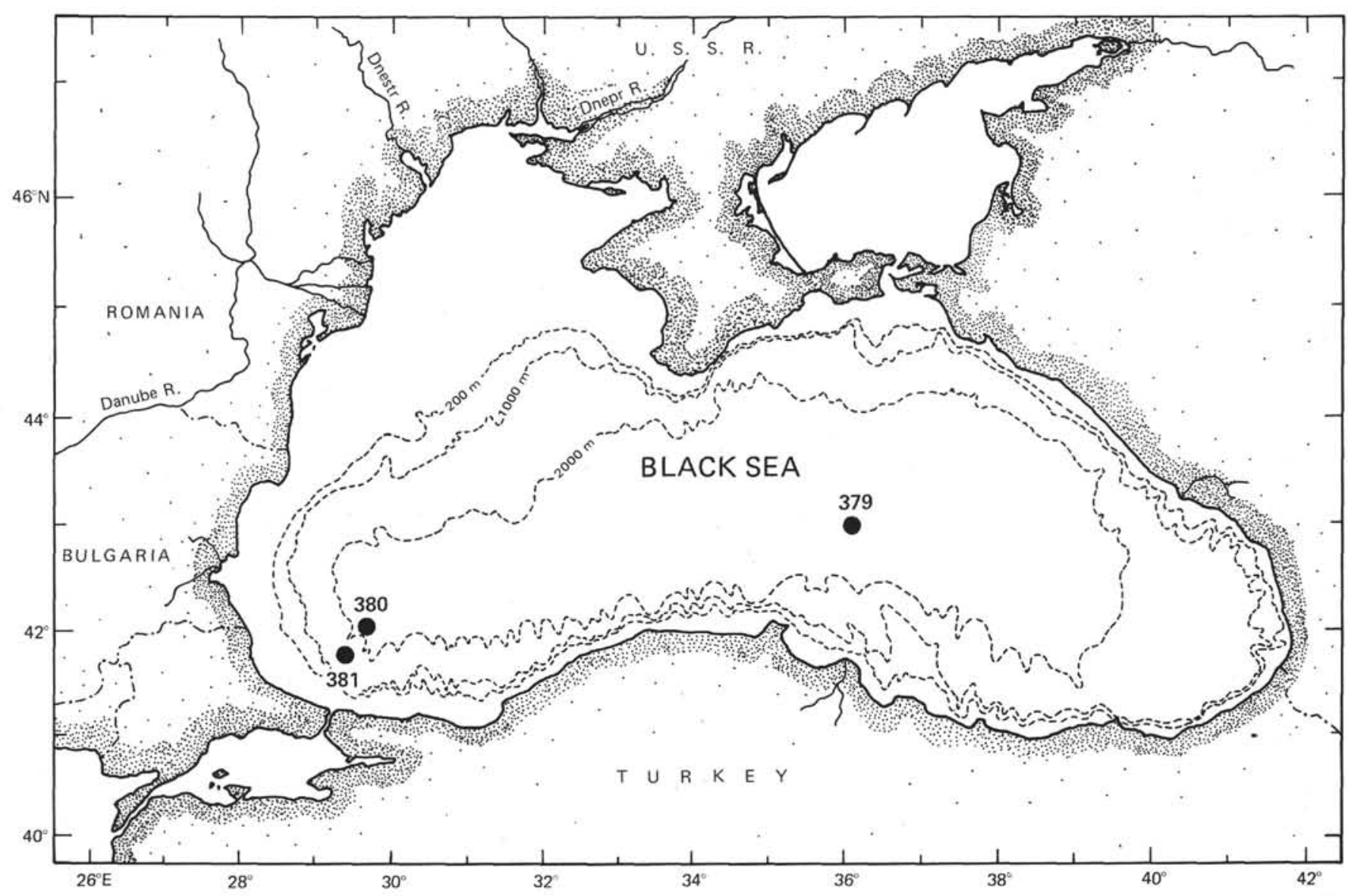

Figure 1. Leg $42 B$ drill sites. 
TABLE 1

Leg 42B Coring Summary

\begin{tabular}{|c|c|c|c|c|c|c|c|c|c|}
\hline Hole & Dates (1975) & Latitude $(\mathrm{N})$ & Longitude (E) & $\begin{array}{c}\text { Water } \\
\text { Depth } \\
(\mathrm{m})\end{array}$ & $\begin{array}{l}\text { Penetration } \\
\text { (m) }\end{array}$ & $\begin{array}{l}\text { No. of } \\
\text { Cores }\end{array}$ & $\begin{array}{l}\text { Meters } \\
\text { Cored }\end{array}$ & $\begin{array}{c}\text { Meters } \\
\text { Recovered }\end{array}$ & $\begin{array}{c}\% \\
\text { Recovery }\end{array}$ \\
\hline 379 & 23 May & $43^{\circ} 00.29^{\prime}$ & $36^{\circ} 00.68^{\prime}$ & 2171 & 7.0 & 1 & 7.0 & 4.0 & 57.0 \\
\hline $379 \mathrm{~A}$ & 23-27 May & $43^{\circ} 00.29^{\prime}$ & $36^{\circ} 00.68^{\prime}$ & 2171 & 624.5 & 68 & 622.0 & 381.0 & 61.3 \\
\hline 379B & 27-28 May & $43^{\circ} 00.29^{\prime}$ & $36^{\circ} 00.68^{\prime}$ & 2171 & 159.0 & 9 & 80.5 & 29.3 & 36.4 \\
\hline 380 & 30 May/1 June & $42^{\circ} 05.98^{\prime}$ & $29^{\circ} 36.90^{\prime}$ & 2115 & 370.5 & 40 & 370.5 & 169.5 & 45.7 \\
\hline $380 \mathrm{~A}$ & 1-7 June & $42^{\circ} 05.94^{\prime}$ & $29^{\circ} 36.82^{\prime}$ & 2115 & 1073.5 & 79 & 734.5 & 421.5 & 57.4 \\
\hline 381 & 8-10 June & $41^{\circ} 40.25^{\prime}$ & $29^{\circ} 24.96^{\prime}$ & 1750.5 & 503.5 & 54 & 1503.5 & 269.5 & 53.5 \\
\hline Totals & & & & & 2738.0 & 251 & 2318.0 & 1274.8 & 55.0 \\
\hline
\end{tabular}

white dolomite, some of which occurs in small burrows in the underlying clay. The uppermost part of each cycle is a yellowish colored layer of dolomite. All boundaries are generally distinct.

The sediments are all of Pleistocene age, although older reworked fossils are common. Indigenous calcareous nannoplankton (of late Quaternary age) are found only in the top 92 meters; below this occasional nannoplankton are reworked. Evidence from other fossil groups (diatoms, ostracodes) indicates periods of fresh or brackish water conditions were common in the past. By using ratios of typical Steppe to Forest forms of spores and pollen, three cool or Steppe periods (called Alpha, Beta, and Gamma) and three warmer or Forest periods (called Celia, Betty, and Anna) were distinguished which, besides being of environmental importance, permit some degree of correlation with Site 380.

On-board measurements of interstitial water salinity showed wide fluctuations in values in the upper part of the hole, indicating rapid changes of the environment from marine to lacustrine. A marked increase in salinity, and especially calcium and magnesium occurs toward the bottom, reaching $40.5 \% \mathrm{dS}$ and 120 and $83 \mathrm{mmole} / \mathrm{l}$ of calcium and magnesium, respectively. The cal ium concentration is more than 10 times that of normal sea water, and is presumed to be formed by $\mathrm{MgCl}$-rich residual brines reacting with calcium carbonate to form dolomite, noted in the basal cores.

Twelve temperature measurements were made at the site. The data show a nearly linear increase in temperature with depth at a rate of 3.2 to $4.0^{\circ} \mathrm{C} / 100$ meters. In general, however, the physical properties program at this site was not very successful due to core disturbance by gas expansion.

One main objective at the site had been to obtain as complete as possible a Plio-Pleistocene section. We were not completely successful because sedimentation rates were much higher than anticipated, and the decision was made to pursue this main objective at Site 380 where the sedimentary sequences appeared to be thinner.

\section{Site 380}

Site 380 is located near the Bosporus $\left(42^{\circ} 05.94^{\prime} \mathrm{N}\right.$, $29^{\circ} 36.82^{\prime}$ E) on the basin apron of the Black Sea in a water depth of 2107 meters. Total penetration was 1073.5 meters sub-bottom; the oldest sediments recovered are a questionable, late Miocene in age.
Five major sedimentological units (with some subunits) were distinguished: (1) muds, sandy silts (from 0 to $332.5 \mathrm{~m}$ depth); (2) marls, muds, varves, dolomite, dolomitic marls, and calcareous ooze (seekreide) (from 332.5 to $448 \mathrm{~m}$ ); (3) calcareous oozes (seekreide); marls (from 448 to 646 m); (4) marls, laminated clays, laminated carbonates with siderite and dolomitic intercalations (from 646 to $969 \mathrm{~m}$ ); (5) black shales (from 969 to $1074 \mathrm{~m}$ ). In general, then, the upper part of the section is of terrigenous origin whereas chemical sediments are more typical of the lower 600 or 700 meters. Sedimentation rates of $30-40 \mathrm{~cm} / 1000 \mathrm{yr}$ appear likely for the Quaternary section.

Sediments having high amounts of carbonate intercalation, called seekreide (lake chalk) because of their similarity to sediments found in some modern Swiss lakes, are common in the lower and middle parts of the section.

Spores and pollen were the most useful fossils at this site allowing a zonation into steppe (glacial) and forest (interglacial) vegetation. This allowed a subdivision of the Quaternary record into three colder drier intervals (Alpha, Beta, Gamma) and four warmer periods (pre-Alpha, Anna, Betty, Celia). These can be used for correlation between sites, although controversy exists concerning correlation (see Summary chapter, this volume).

Indigenous calcareous nannoplankton are relatively rare although reworked forms are common. Planktonic foraminifers were not present and benthic forms were rare. Ostracodes, diatoms, otoliths, siliceous spicules, and mollusks occur at discrete intervals.

The interstitial water program showed that dominating other pore water features in the site, is a slow, smooth increase in salt content with depth, reaching a maximum of about $98 \%$ salinity in the deepest investigated strata. This indicates a brine or evaporite source well below the penetrated strata, and appears to require considerable time to allow diffusion to smooth the curves. The smoothness is also in strong contrast to much more marked "paleosalinity" features in Site 379. Cores were generally very gassy, although the critical methane/ethane ratio stayed within acceptable limits. The gassiness of the cores made measurement of physical properties difficult, but those measurements which were valid showed a controlling influence by sediment type. Sound velocity increased in the lower 200 meters of the hole, going from $1.75-2.1 \mathrm{~km} / \mathrm{sec}$ up to 2.9 $5.9 \mathrm{~km} / \mathrm{sec}$. The geothermal gradient was measured as $35^{\circ} \mathrm{C} / \mathrm{km}$, very close to the $36^{\circ} \mathrm{C} / \mathrm{km}$ measured at Site 379 . The internal heat flow value is $0.99 \mathrm{HFU}$ in good agreement to the $0.98 \mathrm{HFU}$ value at Site 379 . 


\section{Site 381}

In order to maximize the chance of sampling older sediments, Site $381\left(41^{\circ} 40.25^{\prime} \mathrm{N}, 29^{\circ} 24.96^{\prime} \mathrm{E}\right)$ was located upslope of Site 380 , at a water depth of 1728 meters, in an area of possible unconformities. The hole was continuously cored to a depth of 503.5 meters and bottomed in an upper Miocene siltstone.

Nine sedimentary units were described from this site; again the dominant sediment types are terrrigenous muds and chemical sediments (chiefly seekreide). The presence of breccia, shellhash, and certain distinctive faunal elements indicated occasions of deposition under very shallow water conditions, even possibly subaerial exposure.

The faunal record, especially the pores and pollen, are not as complete as at Sites 379 and 380; the cool period Beta appears to be absent and Alpha is somewhat reduced; these data are useful but not conclusive in establishing correlation with the other two sites.

Pore fluids did not show the fresh-water sequences common at the other sites, salinity decreased below 360 meters which is also different than that of the other sites. It could be concluded that some of the sedimentary section is missing, a point also indicated by some stratigraphic evidence.

The correlation between seismic reflecting horizons and the lithostratigraphic column is good at Site 381 .

\section{OPERATIONS SUMMARY}

The Glomar Challenger left its anchorage off Istanbul at 2200 hours on 21 May 1975 on course for Site 379; she returned at 0600 hours on 11 June for a total cruise length just over 20 days, covering a distance of 793 nautical miles. Six holes were drilled at three sites, in water depths ranging from 1750 to 2171 meters. Due to the short distances between sites, only four days were spent cruising; the time breakdown for the remaining 16 days on station is shown in Figure 2. Total penetration was 2738 meters: 252 cores were taken, representing a total recovery of 1275 meters. Coring data are listed in Table 1.

Coring operations at the three sites were remarkably routine. The bottom-hole assembly used at all sites was as follows: bit, core barrel, three $8^{1 / 4}$-inch drill collars, two Baasch-Ross bumper subs, two $81 \frac{1}{4}$-inch drill collars, one $71 / 4$-inch drill collar, one joint $5 \frac{1}{2}$-inch heavy weight drillpipe. The special 10-inch F940P core bit designed for the pressure core barrel was used at all sites. Except for a special hole (379B) cut for spaced geochemical sampling, coring was continuous, both for stratigraphic completeness and for continuous monitoring of the content of organic gases. Because of excellent weather, it was not necessary to use the motion compensator.

The first prototype testing of the Pressure Core Barrel (PCB) was conducted on Leg 42B. The PCB was run 11 times with varying degrees of success. Gas samples from test run No. 9 (Figure 3) produced a methane to ethane ratio eight times higher than samples from adjacent conventional cores. It is evident that the tool has potential for documenting absolute gas compositions which will permit identification of hydrocarbon pressure gradients in non-reservoir rocks. Also there are significant implications for drilling safety and gas migration phenomena in sedimentary strata. Several tool modifications were recommended as a result of initial PCB prototype testing.

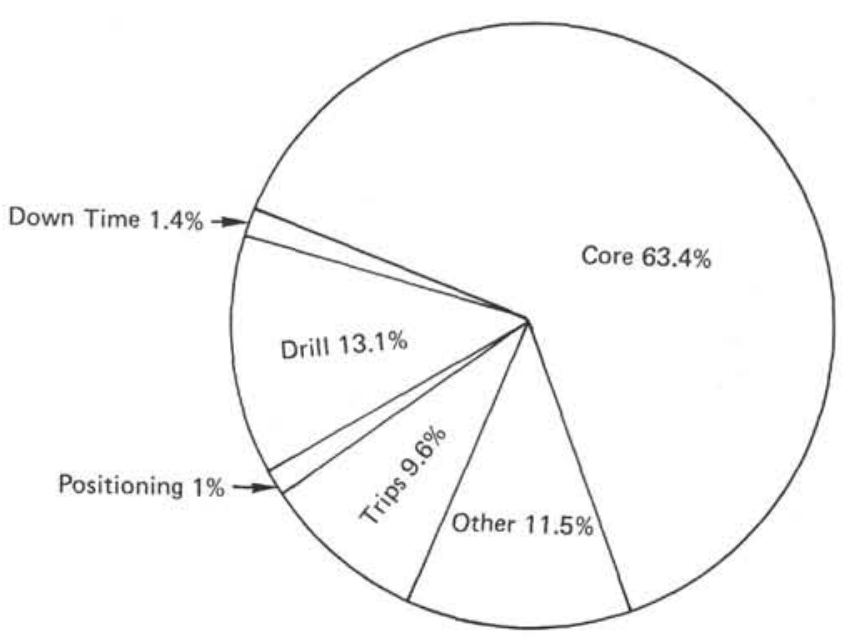

Figure 2. Leg 42B site time breakdown.

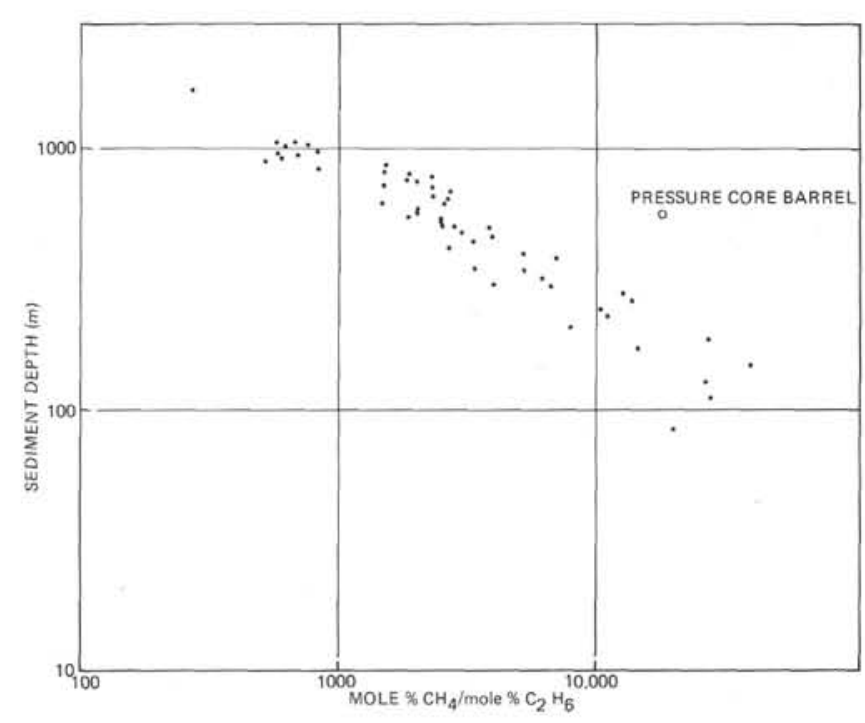

Figure 3. An example of results obtained from the pressure core barrel, the prototype of which was first used on Leg $42 B$.

Persons interested in more detailed account of operational aspects of Leg 42B are advised that report number 8, "Operations Resumés, Legs 34 through 44A" is available from National Technical Information Services, 5259 Port Royal Road, Springfield, Virginia 22151 USA (order ; PB253036, S11.75, microfiche S2.25).

\section{EXPLANATORY NOTES}

\section{Authorship}

The authorship of the site report chapters is the responsibility of the entire scientific party, with final responsibility being with the Co-Chief Scientists. In general, sections were written as follows:

Background and Objectives (Ross)

Operations (Ross)

Lithology (379 and 381, Degens and Stoffers; 380, Hsü)

Biostratigraphy (Traverse and Percival)

Organic Chemistry (Hunt)

Geochemistry (Manheim) 
Physical Properties (Erickson)

Heat Flow (Erickson)

Correlation of reflectors with Lithology (Neprochnov)

Summary and Conclusions (Ross and Neprochnov)

\section{Numbering of Sites, Holes, Cores, Samples}

Drill site numbers run consecutively from the first site drilled by Glomar Challenger in 1968, so the site number is unique. A site refers to the hole or holes drilled from one acoustic positioning beacon. Several holes may be drilled at a single location by pulling the drill string above the sea floor ("mud line") and offsetting the ship some distance (usually $100 \mathrm{~m}$ or more) from the previous hole.

The first (or only) hole drilled at a site takes the site number. Additional holes at the same site are further distinguished by a letter suffix. The first hole takes only the site number; the second takes the site number with the suffix A; the third takes the site number with suffix B; and so forth. It is important, for sampling purposes, to distinguish the holes drilled at a site, since recovered sediments or rocks usually do not come from equivalent positions in the stratigraphic column at different holes.

Cores are numbered sequentially from the top down. In the ideal case, they consist of 9 meters of sediment or rock in a plastic liner of $6.6 \mathrm{~cm}$ diameter. In addition, a short sample is obtained from the core catcher (a multifingered device at the bottom of the core barrel which prevents cored materials from sliding out during core-barrel recovery). This usually amounts to about $20 \mathrm{~cm}$ of sediment and is stored separately. This sample, from each core, represents the lowest stratum recovered in the particular cored interval. The core-catcher sample is designated by CC (e.g., 379-4, $\mathrm{CC}$, core-catcher sample of the fourth core taken at Site 379).

The cored interval is the interval in meters below the sea floor, measured from the point at which coring for a particular core was started to the point at which it was terminated. This interval is generally 9.5 meters (nominal length of a core barrel), but may be shorter if conditions dictate. Cores and cored intervals need not be contiguous. In soft sediments, the drill string can be "washed ahead" without recovering core by applying sufficiently high pump pressure to wash sediment out of the way of the bit.

When a core is brought aboard Glomar Challenger, it is labeled, and the plastic liner and core are cut into 1.5-meter sections. A full, 9-meter core would thus consist of six sections, numbered from the top down, 1 to 6 . (The discrepancy between the $9-\mathrm{m}$ core and $9.5-\mathrm{m}$ cored interval is discussed below.) Generally something less than 9 meters is recovered. In this case, the sections are still numbered starting with one at the top, but the number of sections is the number of 1.5 -meter intervals needed to accommodate the length of core recovered; this is illustrated in Figure 4.

Thus, as shown, recovery of 3.6 meters of sediment would result in a core with three sections, with a void of 0.9 meters at the top of the first section (Figure 5). By convention, and for convenience in routine data handling at the Deep Sea Drilling Project, if a core contains a length of material less than the length of the cored interval, the recovered material is placed in the top of the cored interval, with the top of Section 1, rather than the top of the sediment,

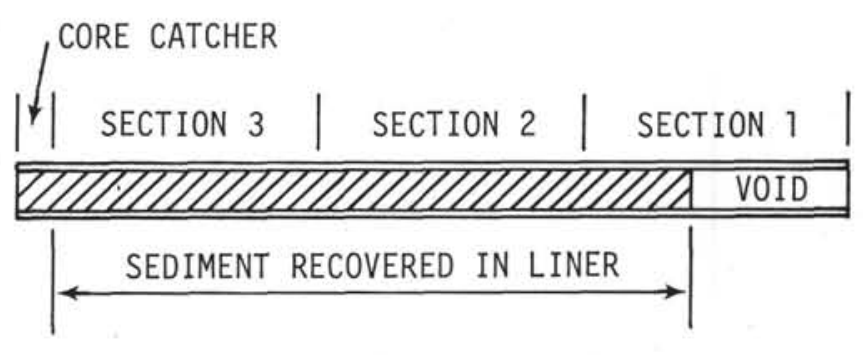

Figure 4. DSDP core labeling conventions.

equal to the top of the cored interval. This is shown below for the core in the above sample.

Thus the depth below the sea floor of the top of the sediment of this hypothetical core would lie at 150.9 meters (not $150.0 \mathrm{~m}$ ) and the bottom at 154.5 meters (the corecatcher sample is regarded as being dimensionless).

It was noted above that a discrepancy exists between the usual coring interval of 9.5 meters and the 9-meter length of core recovered. The core liners used are actually 9.28 meters in length, and the core catcher accounts for another 0.2 meters. In cases where the core liner is recovered full to the top, the core is still cut into six 1.5 -meter sections, measured from the bottom of the liner, and the extra 0.28 -meter section at the top is designated Section 0 , or the "zero section." The zero section is ignored in calculations of depth below the sea floor of cores or levels within cores.

In the core laboratory on Glomar Challenger, after routine processing, the 1.5 -meter sections of sediment core and liner are split in half lengthwise. One half is designated the "archive" half, which is described by the shipboard geologists, and photographed: and the other is the "working" half, which is sampled by the shipboard sedimentologists and paleontologists for further shipboard and shore-based analysis.

Samples taken from core sections are designated by the interval in centimeters from the top of the core section from which the sample was extracted: the sample size, in cc, is also given. Thus, a full sample designation would consist of the following information:

Leg (optional)

Site (hole, if other than first hole)

Core number

Section number

Interval in centimeters from top of section

Site 379A-1-2, 122-124 cm (10 cc) designates a 10-cc sample taken from Section 2 of Core 1 from the second hole drilled at Site 379. The depth below the sea floor for this sample would then be the depth to the top of the cored interval ( $150 \mathrm{~m}$ in the example above), plus 3 meters for Sections 1 and 2, plus $122 \mathrm{~cm}$ (depth below the top of Section 3), or 154.2 meters. (Note, however, that sample requests should refer to a specific interval within a core section [in centimeters] rather than level [m] below sea floor.)

\section{Core Handling}

The first assessment of the core material was made on samples from the core catcher. 


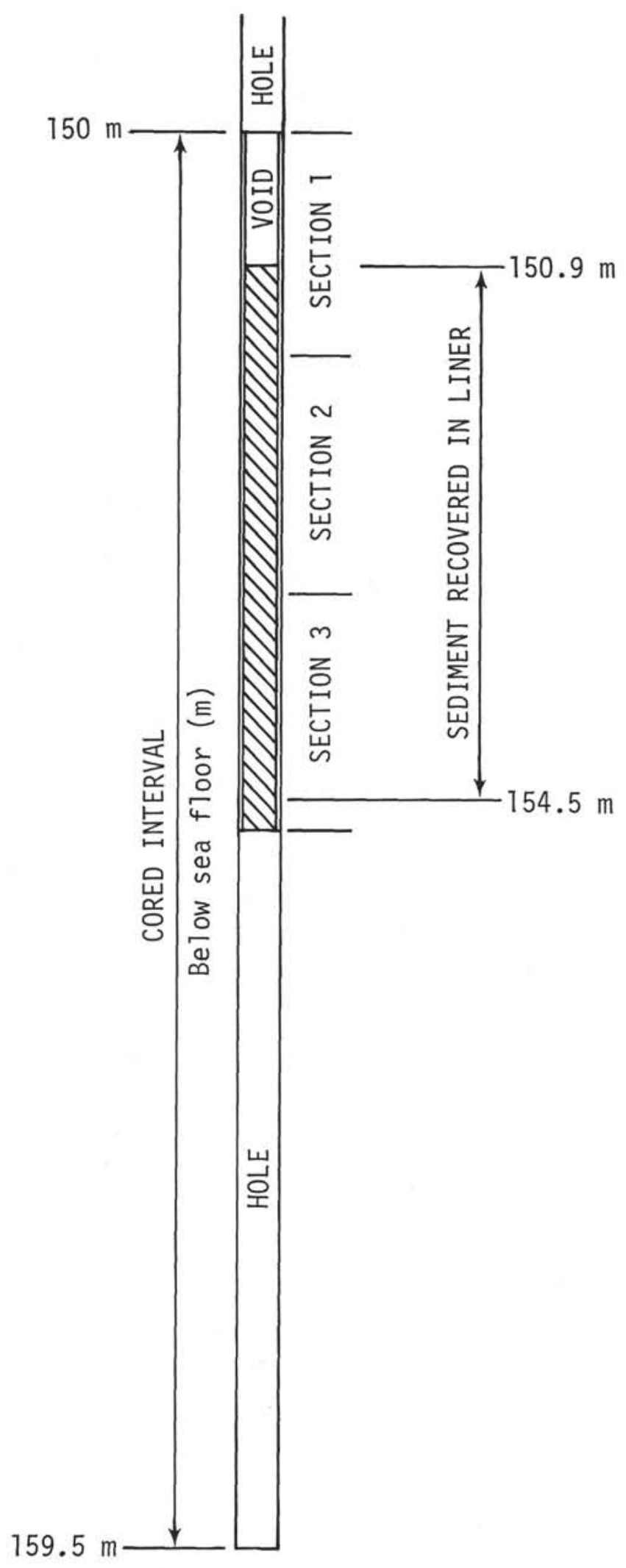

Figure 5. DSDP core depth conventions.
After a core section had been cut, sealed, and labeled, it was brought into the core laboratory for processing. The routing procedure listed below was usually followed:

1) weighing of the core section for mean bulk density measurement;

2) GRAPE analysis for bulk density;

3) sonic velocity determinations; and

4) thermal conductivity measurements.

After the physical measurements were made, the core liner was cut, and the core split into halves by a wire cutter, if the sediment was a soft ooze. If compacted or partially lithified sediments were included, the core was split by a machine band saw or diamond wheel.

One of the split halves was designated a working half. Samples, including those for grain size, X-ray mineralogy, interstitial water chemistry, and total carbon, organic carbon, and carbonate content were taken, labeled, and sealed. Larger samples were taken from suitable cores for organic geochemical analysis, usually prior to splitting the core. The working half was then sent to the paleontology laboratory. There, samples for shipboard and shore-based studies of microfossil groups were taken.

The other half of a split section was designated an archive half. The cut surface was smoothed with a spatula to emphasize the sedimentary features. The color, texture, structure, and composition of the various lithologic units within a section were described on standard visual core description sheets (one per section), and any unusual features noted. A smear slide was made, usually at $75 \mathrm{~cm}$ if the core was uniform. However, two or more smear slides were often made, one for each area of distinct lithology in the core section. The archive half of the core section was then photographed. Both halves were sent to cold storage on board ship after they had been processed.

Material obtained from core catchers, and not used up in the initial examination, was retained in freezer boxes for subsequent work. Sometimes significant pebbles from the core were extracted and stored separately in labeled containers. On other occasions, the liners would contain only sediment-laden water. This was usually collected in a bucket and allowed to settle, and the residue was stored in freezer boxes.

All samples are now deposited in cold storage at the East Coast Repository at Lamont-Doherty Geological Observatory, and are available to investigators.

\section{Core Disturbance}

The rotary drill-coring technique quite often results in a high degree of disturbance of the cored sediments. This is especially true of the softer unconsolidated sediments. A qualitative estimate of the degree of deformation is given on the core logs. ${ }^{1}$

\section{Core Forms}

The basic lithologic data are contained on core summary forms. As far as possible the data are presented in the following order:

Sediment or rock name

Sediment Disturbance and Sedimentary Structures

\footnotetext{
${ }^{1}$ On Leg 42B there was an abnormally high degree of core disturbance due to gas expansion.
} 
Color name and Munsell or GSA number

(The reader is advised that colors recorded in core barrel summaries were determined during shipboard examination immediately after splitting core sections. Experience with carbonate sediments shows that many of the colors will fade or disappear with time after opening and storage. Colors particularly susceptible to rapid fading are purple, light and medium tints of blue, light bluish gray, dark greenish black, light tints of green, and pale tints of orange. These colors change to white or yellowish white or pale $\tan$.)

Composition via smear slides

Grain size, carbon-carbonate, and X-ray data

Many cores contain important minor lithologies as well as a basic lithology. The description of the basic lithology is so indicated in most cases, however, descriptive information for minor lithologies is included wherever possible.

A sample core form is shown as Figure 6. On this sample form is contained all legend and explanatory notes for an understanding of the core forms.

\section{Smear Slides}

Smear slides are the basic means of mineral identification for sediments on shipboard. Smear-slide estimates of mineral abundances were based on area of the smear slide covered by each component. Past experience has shown that accuracy may approach a percent or so for very distinctive minor constituents but that, for major constituents, accuracy of \pm 10 to $20 \%$ is considered very good. Of more importance to the geologist than absolute accuracy are relative changes in component abundances.

In some cases "dominant lithology" smear-slide estimates represent averages of several slides and hence are not labeled by discrete location. Other smear slides are marked by discrete label, i.e., $2 / 123 \mathrm{~cm}$ would indicate a depth of $123 \mathrm{~cm}$ in Section 2 of that core.

\section{Grain Size Analyses}

All grain size analysis results presented on core forms were obtained by scientists of the MineralogischePetrologisches Institut der Universität Heidelberg. Standard sieving and settling tube techniques were used. Results are presented to the nearest percent.

In some cases, smear-slide data include textural information, particularly in the case of clastic sediments. When present, these data are included in brackets above the compositional data and are designated thus: $\mathrm{n} 0,20,80 \mathrm{~m}$ means $0 \%$ sand, $20 \%$ silt, $80 \%$ clay. Note that these visual estimates are more likely to be less accurate.

\section{Carbon-Carbonate Analyses}

Percentages of total $\mathrm{CaCO}_{3}$ and of organic carbon were determined by burn technique by colleagues in the laboratories of the Atlantic Division, P.P. Shirshov Institute of Oceanology, Kaliningrad, U.S.S.R. Values for $\mathrm{CaCO}_{3}$ are presented to the nearest percent, values of organic carbon to the nearest tenth of a percent.

In addition, total carbonate was determined for selected $\mathrm{X}$-ray mineralogy samples by the use of an acidificationpressure bomb technique (Müller and Gastner, 1974).

\section{X-ray Mineralogy}

$\mathrm{X}$-ray data presented are all bulk analyses performed at Heidelberg using a Phillips X-ray diffractometer and the $\mathrm{X}$-ray computer program of the USGS at Woods Hole (Hathaway, unpublished). Data processing was as described by Zemmels et al. (1972).

$$
\begin{aligned}
& \text { Mineral species are listed as follows: } \\
& \mathrm{C}=\text { Calcite } \\
& \mathrm{D}=\text { Dolomite } \\
& \mathrm{MgC}=\text { High magnesian calcite }\left(\times 7 \mathrm{Mo} 1 / \mathrm{MgCO}_{3}\right) \\
& \mathrm{A}=\text { Aragonite } \\
& \mathrm{S}=\text { Siderite } \\
& \mathrm{Q}=\text { Quartz } \\
& \mathrm{F}=\text { Feldspar } \\
& \text { L.S. }=\text { Layered silicates } \\
& \mathrm{P}=\text { Pyrite }
\end{aligned}
$$

Data are presented to the nearest percent or as trace (Tr). For most X-ray samples containing carbonate, the percentage carbonate was determined independently by using the carbonate bomb method. X-ray and bomb results were in fairly good agreement often agreeing within $10 \%$. The bomb results were accepted as correct by convention and the $\mathrm{X}$-ray results were corrected and recalculated to $100 \%$ on this basis. When siderite was present, similar corrections were applied by first chemically determining the iron present, then correcting for carbonate in the siderite.

Note that clay minerals are not specifically differentiated, but are reported simply as bulk percentage of layered silicates. Since this determination is based on the $\sim 4.5 \equiv \AA$ peak area, it is affected by the presence of amorphous silica; the layered silicate percentage will include any diatoms present in the sample.

\section{Sediment Classification}

The sediment classification used here was devised by the JOIDES Panel on Sedimentary Petrology and Physical Properties, and adopted for use by the JOIDES Planning Committee in March $1974 .^{2}$.

The accompanying set of lithologic symbols (Figure 7) has been applied as in past DSDP cruises, with, however, some slight modification due to several unique characteristics of Leg 42B. First, since the cored section consisted of lacustrine sediments over $>90 \%$ of its depth, several new rock types were encountered. Thus, symbols CB4 and CB8 (calcareous ooze and calcareous chalk) usually are used in the marine case to designate fine carbonate flour or nondiagnostic chalk (the term "micarb" had been suggested and used for this fine-grained carbonate) which may represent fine detrital carbonate or an intermediate or end product in the diagenetic alteration of biogenic ooze. For Leg 42B, we use these symbols to represent what we term seekreide a fine-grained low magnesian calcite sediment of silt-to-clay size commonly found in fresh-water lakes. Although a portion of the seekreide may represent original carbonate detritus, at least a portion is chemically precipitated, as seen by scanning electron photomicrography.

Siderite is a locally abundant component of the Black Sea lacustrine section. Where it occurs as grains in unconsoli-

\footnotetext{
${ }^{2}$ It appears as an appendix to this chapter.
} 
D. A. ROSS, Y. P. NEPROCHNOV, P. R. SUPKO

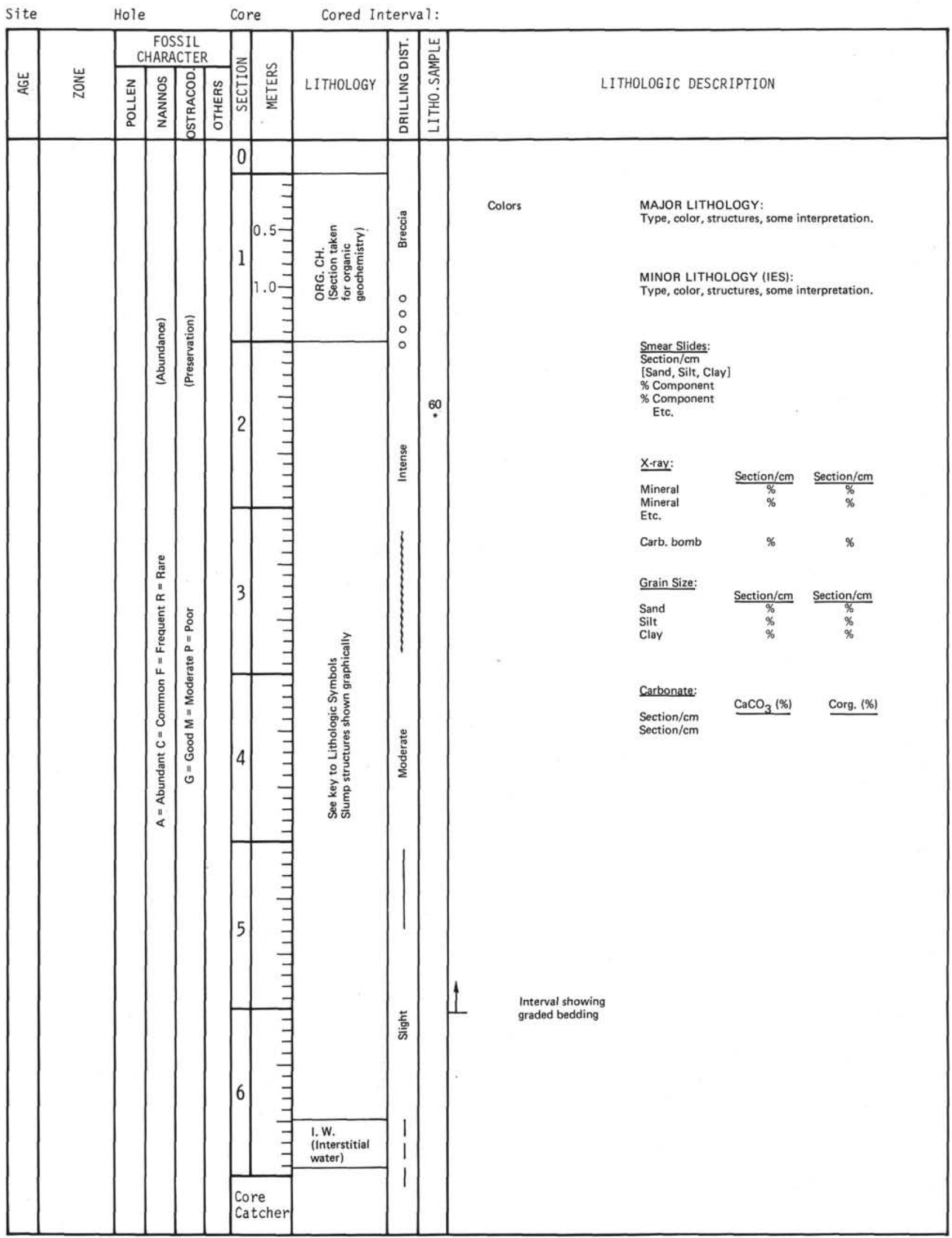

Figure 6. DSDP sample core form. 
Pelagic

Non-biogenic

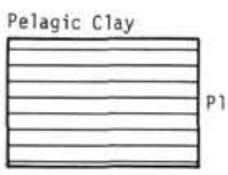

Siliceous Biogenic

Pelagic Siliceous Biogenic - Soft

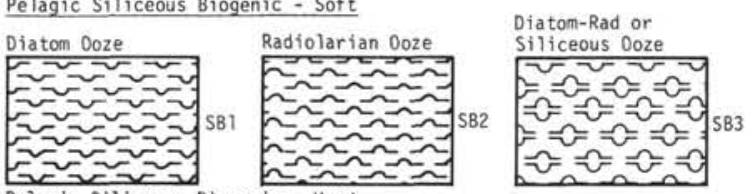

Vertical bar percent

(D) Designation
for Graphic Log.

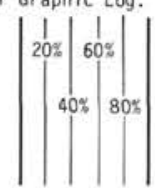

Pelagic Siliceous Biogenic - Hard
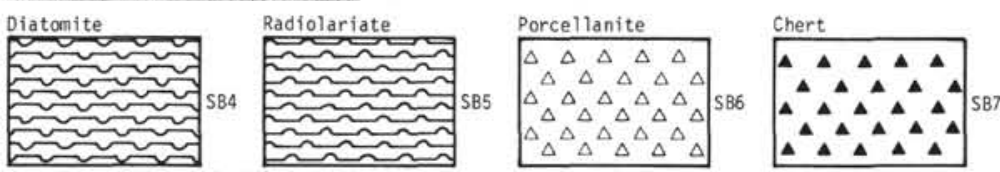

Transitional Biogenic Siliceous Sediments

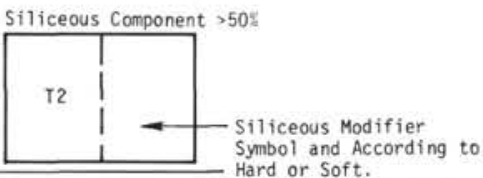

Calcareous Biogenic

Pelagic Biogenic Calcareous - Soft

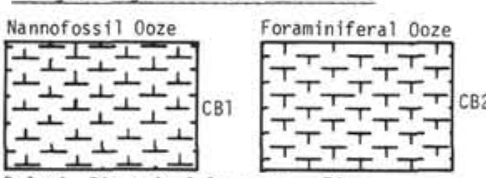

Pelagíc Biogenic Calcareous - Firm

Nannofossil Chalk

Pelagic Biogenic Calcareous - Hard

Limestone

Siliceous Component $<50 \%$ Hard or Sof $t$.

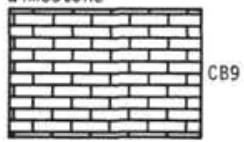

Nanno-Foram or

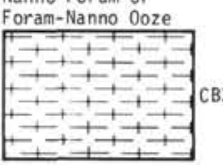

Calcareous Ooze

B33

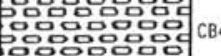

Nanno-Foram or

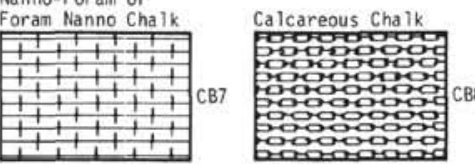

Transitional Biogenic Calcareous Sediments

Mar1

Siderite Layer
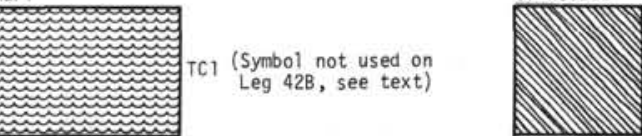

\section{Terrigenous Sediments}

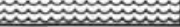

Leg $42 B$, see text
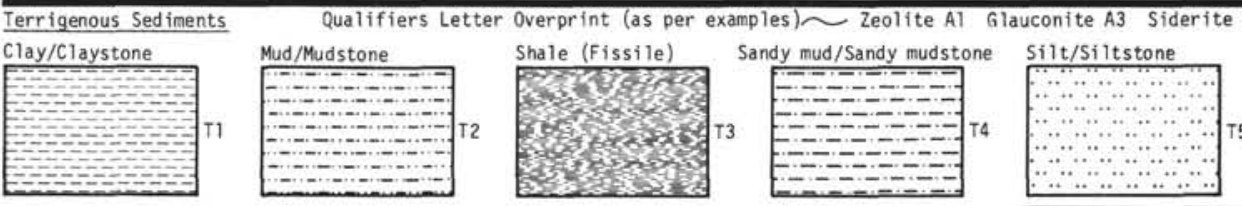

other may be designated

Shell Hash
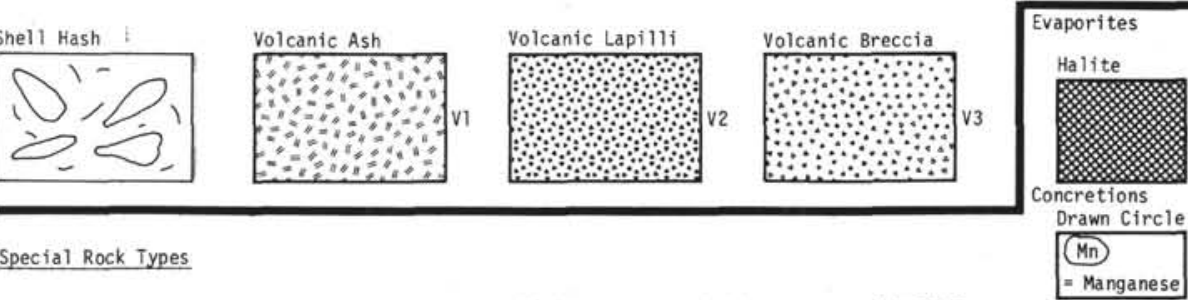

Special Rock Types
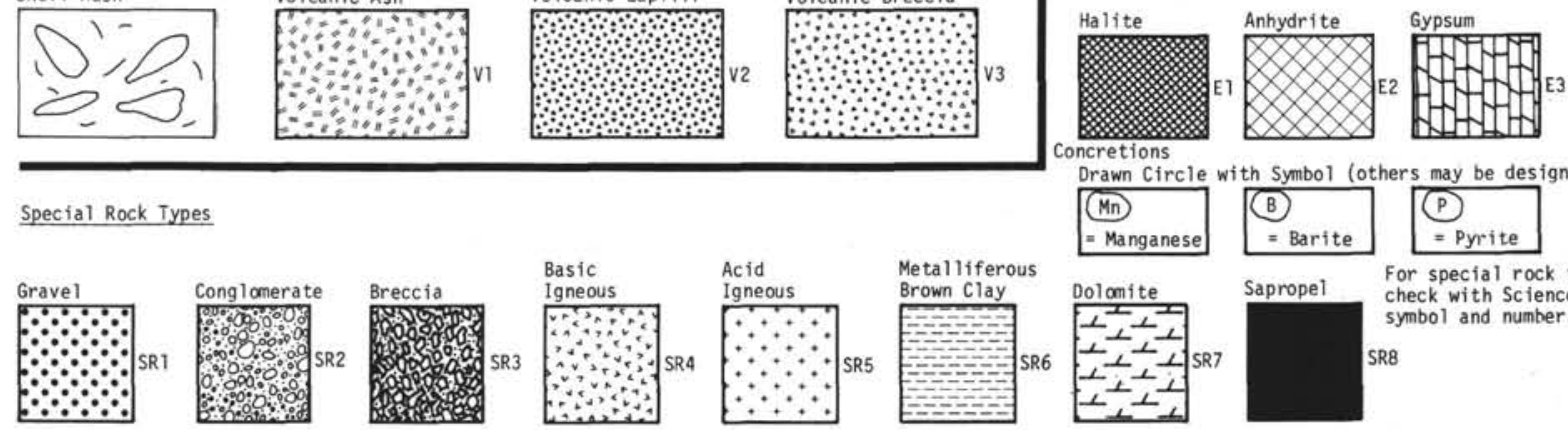

Sand/Sandstone

Figure 7. Graphic symbols used in DSDP lithologic classification. 
dated section, its presence is indicated by overprinting of the letter "S."' Hard siderite layers or nodules have a separate symbol (see Figure 7).

Because of the very fine alternation of laminae in much of the cored section, and because of the rapidity with which cores were received on deck, symbology on many of the core forms tends to be schematic and generalized rather than literal. The sample requestor is thus cautioned to refer carefully to the information on the core forms and to be specific in his needs when requesting samples from the DSDP Curatorial Staff, who are trained in geology.

\section{Biostratigraphy}

Shipboard age assignments were impossible to make because of lack of definitive fossils. The few indigenous coccoliths were of some use, however, in assessing paleosalinity conditions, as were pollen and some of the more distinctive diatoms. Pollen and spores and diatoms were the most useful fossil group. Traverse (this volume) describes the "Steppe-Forest Index" used as a general climatic indicator and the "Marine-Influence Index" used to give a rough idea of paleosalinity. Diatoms, although generally too useful for dating (Jousé and Mukhina, this volume, did establish a stratigraphy), were very valuable for interpreting environmental changes (Schrader, this volume). Most information gained from study of fossils from the Black Sea cores has come as a result of shore-based studies. The reader is referred to the nine papers comprising Part VI of this volume.

\section{Chemistry}

\section{Interstitial Water Sampling and General Procedures}

Ten-cm long core sections were normally sawed off the ends of core sections immediately after recovery of the core on deck, capped, and taken below to the chemical laboratory. There, electrical resistivity probes (Manheim et al., 1974) were inserted in end sections. Subsequently, outer contaminated layers were trimmed off and broken up (where hard core was obtained); inner portions were quickly emplaced in special stainless squeezers, and fluid extracted. Owing to continuous coring policy, it was unfeasible to attempt to squeeze samples under temperature controlled conditions. (For photographs and more detail, see Explanatory Notes in Whitmarsh, Weser, Ross, et al., 1974).

The $p \mathrm{H}$ on 0.5 to $1 \mathrm{ml}$ fluid samples was determined by electrode in test tubes. "Salinity" was determined on a few drops of fluid by means of a Goldberg Refractometer (American Optical Co.) to the nearest $0.1 \%$, and alkalinity, $\mathrm{Ca}$, and $\mathrm{Mg}$ were analyzed on $1 \mathrm{ml}$ or less of fluid. The remainder was packaged and archived in glass vials or heat sealed in polyethylene pipe (propane torch and forceps).

Alkalinity was determined on direct titration with 0.005 $M$ (or weaker) $\mathrm{HCl}$, using the Bruevich mixed color reagent, methyl red and methylene blue. $\mathrm{CO}_{2}$ was removed by bubbling with a He stream from the carrier gas used in gas chromatography. Samples were added to distilled water which had been titrated to the green-purple color change point to remove blank.

Calcium and magnesium were determined by micromodifications (J. Gieskes, Scripps Institution) of complexometric titration techniques.
Electrical resistivity measurements to establish diffusive permeability are discussed more fully in Manheim (this volume) and in Manheim et al. (1974). At times, resistivity measurements were also performed on length-split halves, using special calibration methods. For hard samples, especially lithified carbonates, holes were pre-drilled using templates before inserting probes. The holes were mo stened with sea water to assure electrical contact.

\section{Deuterium/oxygen Isotope Analysis on Pore Fluids}

Samples archived in glass ampules were separated for shipment to I. Friedman and K. Hardcastle, U.S. Geological Survey, Denver (see report attached to Manheim and Schug, this volume).

\section{Halogen Analysis}

Splits of polyethylene pipe-packaged pore fluids were sent to O.V. Shishkina at the Institute of Oceanology, Moscow, for bromine and iodine analysis (see Shishkina, this volume).

\section{Major and Minor Elements in Solids}

Samples were taken, chiefly in the upper core lab, at varying intervals. After splitting cores, samples from appropriate intervals were packaged for shipment to a number of analytical laboratories for a variety of analytical treatments. See appropriate Chapters in Part IV of this volume.

\section{Organic Geochemistry}

Early in the planning phases, Leg 42B was designated as a cruise which would give emphasis to sample collection for numerous shore-based organic geochemistry studies. The shipboard sampling was undertaken under the direction of John Hunt; numerous samples, some entire core sections and, in the case of Site 379, entire cores collected from a separate drill hole, were frozen for later subsampling ashore, Part V of this volume comprises sixteen chapters on organic geochemistry of Black Sea sediments.

\section{Physical Properties}

The standard Glomar Challenger techniques for the measurement of physical properties have been thoroughly described by Boyce (1973) and will not be repeated here. In general, the gassy, and hence disrupted, nature of the Black Sea cores made them very unsuitable for porosity or wet bulk density measurements by volumetric techniques or by the GRAPE; this was especially true at Site 379 . In such cases, the syringe technique alone had to suffice. Similarly, sonic velocities could be obtained only for those samples which were more consolidated and undisturbed.

Thermal conductivities were measured with a Von Herzen-Maxwell needle probe utilizing an improved instrumentation system developed by WHOI. Heat flow measurements were made in situ using a downhole instrument. The heat flow program was an important one on Leg 42B; technique and results are discussed in Erickson and Von Herzen (this volume).

\section{Underway Geophysics}

The survey data used for specific site selections are given in each Site Report chapter. On passage between sites, con- 
tinuous observations were made of depth, magnetic field, and sub-bottom structure. Underway depths were continuously recorded on a precision graphic recorder (PGR). The depths were read on this basis of an assumed 800 fathoms/ sec sound velocity. The sea depth, in meters, was corrected (1) according to the tables of Matthews (1939) and (2) for the depth of the hull transducer below sea level $(6 \mathrm{~m})$. The seismic profiling system consisted of two Bolt airguns, a Scripps-designed hydrophone array, Bolt amplifiers with two bandpass filters, and two EDO recorders, usually recording at two different filter settings. Underway data are presented in Neprochnov (this volume).

\section{REFERENCES}

Boyce, R.E., 1973. Physical properties methods. In Edgar, N.T., Saunders, J.B., et al., Initial Reports of the Deep Sea Drilling Project, Volume 15: Washington (U.S. Government Printing Office), p. 1115-1128.

Degens, E.T. and Ross, D.A. 1974. The Black Sea - geology, chemistry and biology: Am. Assoc. Petrol. Geol. Mem. 20.

Manheim, F.T. and Waterman, L.S., 1974. Interstitial water studies on small core samples, Leg 23 (Red Sea). In Whitmarsh, R.B., Weser, O.E., Ross, D.A., et al. Initial Reports of the Deep Sea Drilling Project, Volume 23: Washington (U.S. Government Printing Office), p. 955-967.

Matthews, D.J., 1939. Tables of the velocity of sound in pure water and sea water for use in echo-sounding and soundranging: Hydro. Dept. Admiralty, second ed., London.

Wentworth, C.K., 1922. A scale of grade and class terms for clastic sediments: J. Geol., v. 30, p. 377-392.

Whitmarsh, R.B., Weser, O.E., and Ross, D.A., et al., 1974. Initial Reports of the Deep Sea Drilling Project, Volume 23: Washington (U.S. Government Printing Office).

Zemmels, I., Cook, H.E., and Hathaway, J.C., 1972. X-ray mineralogy studies - Leg XI. In Hollister, C.D., Ewing, J.E., et al, Initial Reports of the Deep Sea Drilling Project, Volume 11: Washington (U.S. Government Printing Office, p. 729. 789.

\section{APPENDIX A CLASSIFICATION OF SEDIMENTS}

Several lithologic classifications designed for the construction of the graphic core and hole summaries have been used during the lifetime of the Deep Sea Drilling Project. The classification system described here has been devised by the JOIDES Panel on Sedimentary Petrology and Physical Properties and adopted for use by the JOIDES Planning Committee in March 1974.

\section{Principles Used in Classification}

1. This is a lithologic summary classification designed to generalize core descriptive material of greater detail into a form suitable for standard core and hole logs. Its systematic use will facilitate core to core and leg to leg comparisons.

2. The classification covers most of the lithologic types encountered so far but does not attempt to be comprehensive. A category "Special Rock Types" allows additional definitions and terminology at the discretion of the shipboard staff for rock types not covered.

3. Sediment names are those in common usage and have been defined within the limits of existing definitions.

4. Categories are based on sediment parameters measured on board ship. Refinement by shore laboratory data is possible but not necessary.

5. The classification is descriptive and genetic implications are not intended.

6. The degree of detail of the classification is scaled to the space limitations of printed graphic hole and core summaries.

\section{Shipboard Parameters Measured}

Sediment and rock names are defined solely on the basis of compositional and textural parameters. The compositional factors are most important for description of those deposits more characteristic of open marine conditions, with textural factors becoming more important for the classification of hemipelagic and near-shore facies. Sediment names are thus based solely upon these parameters as determined in smear slides aided by compositional and textural properties apparent to the naked eye or under the hand lens. Other descriptive parameters include: induration, sediment disturbance, sedimentary structures, and color. The determination of these parameters is as follows:

1) Composition-biogenic and mineral components are estimated in percent from smear slides. $\mathrm{CaCO}_{3}$ content is estimated by using the carbonate bomb available on the ship. Even with rapid use, a value to $\pm 5 \%$ is achievable

2) Texture-visual estimates from smear slide examination.

3) Induration-The determination of induration is highly subjective, but field geologists have successfully made similar distinctions for many years. The categories suggested here are thought to be practical and significant. The criteria of Moberly and Heath (1971) are used for calcareous deposits: subjective estimate or behavior in core cutting for others. There are three classes for calcareous sediments: two for all others.

a) Calcareous sediments

(i) Soft: Oozes have little strength and are readily deformed under the finger or the broad blade of a spatula.

(ii) Firm: Chalks are partly indurated oozes: they are friable limestones that are readily deformed under the fingernail or the edge of a spatula blade. More indurated chalks are termed limestones (see below)

(iii) Hard: Limestones as a term should be restricted to cemented rocks.

b) The following criteria are recommended for all but calcareous sediments:

(i) If the material is low state of induration as to allow the core to be split with a wire cutter, the sediment name only is used (e.g., silty clay: mud).

(ii) If the core must be cut on the band saw or diamond saw, the suffix 'stone' is used (e.g., silty claystone: mudstone; or shale, if fissile.)

4) Sediment Disturbance-Deformational structures are generally of the type found in piston cores, and are usually simple to visualize and interpret.

a) Soft to firm sediment: The following categories are recommended.

(i) Slightly deformed-bedding contacts are slightly bent.

(ii) Moderately deformed-bedding contacts have undergone extreme bowing.

(iii) Very deformed-bedding is completely disturbed, sometimes showing symmetrical diapir-like structure.

(iv) Soupy - water saturated intervals which have lost all aspects of original bedding.

b) Hard sediments: There is also the need to indicate the degree of fracturing in hard sediments/rock. This is best accomplished with a written description in the Lithologic Description portion of the Core Form (Figure 6).

5) Sedimentary structures-In many cores it is extremely difficult to differentiate between natural and coring-induced structures. Consequently, the description of sedimentary structures is optional. The following approach is suggested as a guideline, but the specialist is encouraged to use his own preferred system and set of symbols.

a) Median grain size profile: For the sections of terrigenous sediments, with interbeds of varying textural characteristics, the construction of median grain size profile based on hand lens observations provides a rapid method for illustrating graded and non-graded beds, bed thickness, and size distribution.

b) Sedimentary structures: A set of suggested symbols is provided for categories shown on (Figure 8).

6) Color-According to standard Munsell and GSA color charts.

\section{Use of the Core Form}

1) Mandatory Graphic Lithology Column-This graphic column is based on the above classification scheme. Completion of the column using 
the appropriate symbols (Figure 7) must be done for each site, and will be included in the Initial Core Description (ICD) and Initial Report Volume. The "Special Rock Type" category should be used for sediment types not in the classification.

a) Optional graphic column: If circumstances or the special skills and interests of the shipboard staff indicate an additional modified or different classification, another graphic column may be added to the right of the Mandatory Column using definitions, terminology and symbols that, in the opinion of the shipboard staff, will increase the information yield. This Optional Column must not substitute for the Mandatory Column.

2) Sediment disturbance column-Completion of the sediment disturbance column using symbols and distinctions given below is mandatory.

3) Sedimentary structure columns - Structures may be designated on the core form in the sedimentary structure column parallel to the sediment disturbance column, and/or on the median grain size profile (for the sections of terrigenous sediments, with interbeds of varying textural characteristics). The median grain size profile is located in the lithologic description portion of the core form. A set of suggested symbols for a few more common structures has been prepared by DSDP (Figure 8), but the shipboard geologist is free to use whatever additional symbols he may wish. These optional columns may not substitute for the mandatory sediment disturbance column and must be distinct from it.

4) Lithologic description column-Format, style, and terminology of the descriptive portion of the core sheets are not controlled by the mandatory column scheme, beyond the minimal name assignment which should be derived from this classification. However, colors and additional information on structure and textures should normally be included in the textural section of the core description.

\section{Lithologic Classification Scheme}

The following define compositional class boundaries and use of qualifiers in the lithologic classification scheme:

1) Compositional Class Boundaries

a) $\mathrm{CaCO}_{3}$ content (determined by $\mathrm{CaCO}_{3}$ bomb): $30 \%$ and $60 \%$. With a $5 \%$ precision and given the natural frequency distribution of $\mathrm{CaCO}_{3}$ contents in oceanic sediments, these boundaries can be reasonably ascertained.

b) Biogenic opal abundance (expressed as percent siliceous skeletal remains in smear slides): $10 \%, 30 \%$, and $50 \%$. Smearslide estimates of identifiable siliceous skeletal material generally imply a significantly higher total opal abundance. The boundaries have been set to take this into account.

c) Abundance of authigenic components (zeolites, $\mathrm{Fe}$, and $\mathrm{Mn}$ micronodules etc), fish bones, and other indicators of very slow sedimentation (estimated in smear slides); semiquantitative boundary: common $10 \%$. These components are quite conspicuous and a semiquantitative estimate is adequate. Even a minor influx of calcareous, siliceous, or terrigenous material will, because of the large difference in sedimentation rate, dilute them to insignificance.

d) Abundance of terrigenous detrital material (estimated from smear slides): $30 \%$

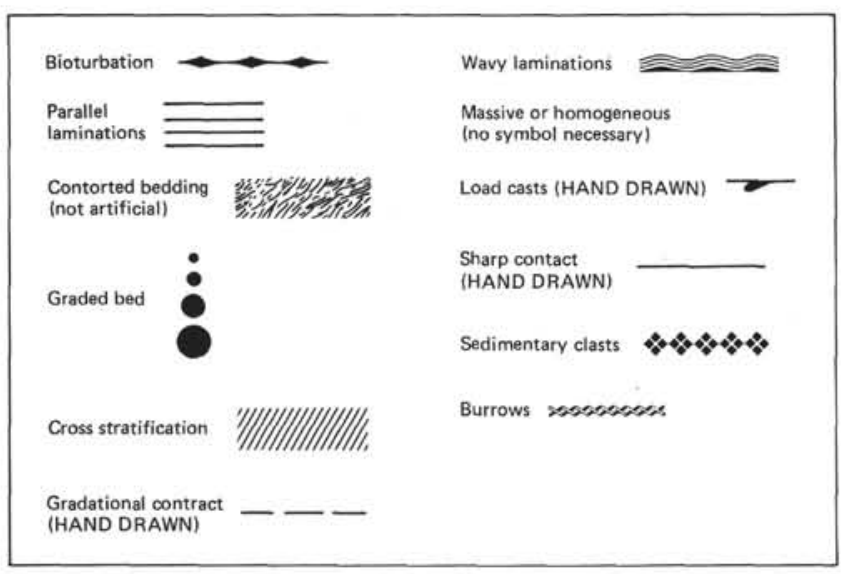

Figure 8. DSDP sedimentary structure symbols.

e) Qualifiers: Numerous qualifiers are suggested; the options should be used freely. However, components of less than 5\% (in smear slide) should not be used as a qualifier except in special cases. The most important component should be the last qualifier. No more than two qualifiers should be used.

\section{Description of Sediment Types}

1) Pelagic clay-Principally authigenic pelagic deposits that accumulate at very slow rates. The class is often termed brown clay, or red clay, but since these terms are confusing, they are not recommended.

a) Boundary with terrigenous sediments: Where authigenic components (Fe/Mn micronodules, zeolites), fish debris, etc., become common in smear slides. NOTE: Because of large discrepancy in accumulation rates, transitional deposits are exceptional.

b) Boundary with siliceous biogenic sediments: $<30 \%$ identifiable siliceous remains.

c) Boundary with calcareous biogenous sediments: Generally the sequence is one passing from pelagic clay through siliceous ooze to calcareous ooze, with one important exception: at the base of many oceanic sections, black, brown or red clays occur directly on basalt, overlain by or grading up into calcareous sediments. Most of the basal clayey sediments are rich in iron, manganese and metallic trace elements. For proper identification they require more elaborate geochemical work than is available on board. These sediments are placed in the "Special Rock" category, but care should be taken to distinguish them from ordinary pelagic clays.

2) Pelagic siliceous biogenic sediments - These are distinguished from the previous category because they have more than $30 \%$ identifiable siliceous microfossils. They are distinguished from the following category by a $\mathrm{CaCO}_{3}$ content of less than $30 \%$. There are two classes: Pelagic biogenic siliceous sediments (containing less than $30 \%$ silt and clay); and transitional biogenic siliceous sediments (containing more than $30 \%$ silt and clay and more than $10 \%$ diatoms).

a) Pelagic biogenic siliceous sediments:

soft: Siliceous ooze (radiolarian ooze, diatom ooze, depending on dominant component).

hard: radiolarite porcellanite diatomite chert

(i) Qualifiers:

Radiolarians dominant: radiolarian ooze or radiolarite.

Diatoms dominant: diatom ooze or diatomite

Where uncertain: siliceous (biogenic) ooze, or chert or porcellanite, when containing $>10 \%$ $\mathrm{CaCO}_{3}$, qualifiers are as follows:

indeterminate carbonate:

$\begin{array}{lll}\text { nannofossils only: } & \text { or } & \text { nannofossil - - } \\ \text { foraminifers only: } & & \text { foraminifer - - } \\ \text { nannofossil-foraminifer }-. & \begin{array}{l}\text { depending on } \\ \text { dominant } \\ \text { component }\end{array}\end{array}$

foraminiferal-nannofossil - -

b) Transitional biogenic siliceous sediments:

Diatoms < $50 \%$ diatomaceous mud: diatomaceous mudstone:

Diatoms $>50 \%$ muddy diatom ooze: muddy diatomite:

soft hard soft hard

Radiolarian equivalents in this category are rare and can be specifically described.

3) Pelagic biogenous calcareous sediments-These are distinguished from the previous categories by a $\mathrm{CaCO}_{3}$ content in excess of $30 \%$. There are two classes: Pelagic biogenic calcareous sediments (containing less than $30 \%$ silt and clay); and transitional biogenic calcareous sediments (containing more than $30 \%$ silt and clay).

a) Pelagic biogenic calcareous sediments: soft: calcareous ooze firm: chalk hard: indurated chalk

The term limestone should preferably be restricted to cemented rocks.

(i) Compositional Qualifiers $\leqslant-$

Principal components are: nannofossils and foraminifers. 
One or two qualifiers may be used, for example:

\begin{tabular}{cl}
$\begin{array}{c}\text { Foram } \% \\
<10\end{array}$ & \multicolumn{1}{c}{ Name } \\
$10-25$ & Foraminiferal-nannofossil ooze \\
$25-50$ & Nannofossil-foraminifer ooze \\
$>50$ for: & Foraminifer ooze
\end{tabular}

Calcareous sediment containing more than 10\%-20\% identifiable siliceous fossils carry the qualifier radiolarian, diatomaceous, or siliceous depending on the quality of the identification. For example, radiolarian-foraminifer ooze.

b) Transitional biogenic calcareous sediments

(i) $\mathrm{CaCO}_{3}=30 \%-60 \%$ : marly calcareous pelagic sediments soft: marly calcareous (or nannofossil, foraminifer, etc.), ooze (see below)

firm: marly chalk

hard: marly limestone

(ii) $\mathrm{CaCO}_{3}>60 \%$ : Calcareous pelagic sediments.

soft: calcareous (or nannofossil, foraminifer, etc.), ooze (see below)

firm: chalk

hard: limestone

NOTE: Sediments containing $10 \%-30 \% \mathrm{CaCO}_{3}$ fall in other classes where they are denoted with the adjective "calcareous." Less than $10 \% \mathrm{CaCO}_{3}$ is ignored.

4) Terrigenous sediments

a) Sediment falling in this portion of the classification scheme are subdivided into textural groups on the basis of the relative preportions of three grain size constituents, i.e., clay, silt, and sand. Rocks coarser than sand size are treated as "Special Rock Types." The size limits for these constituents are those defined by Wentworth (1922) (Figure 9).

Five major textural groups are recognized on the accompanying triangular diagram (Figure 10). These groups are defined according to the abundance of clay $(>90 \%, 90-10 \%,<10 \%)$ and the ratio of sand to silt $(>1$ or $<1)$. The terms clay, mud, sandy mud, silt, and sand are used for the soft or unconsolidated sediments which are cut with a wire in the shipboard core splitting process. The hard or unconsolidated equivalents for the same textural groups are claystone, mudstone (or shale, if fissile), sandy mudstone, siltstone, and sandstone. Sedimentary rocks falling into the consolidated category include those which must generally be cut with the band saw or diamond saw. Sands and sandstones may be subdivided further into very fine-, fine-, medium-, coarse-, or very coarse-grained sands and sandstones according to their median grain size.

(i) Qualifiers-In this group numerous qualifiers are possible, usually based on minor constituents, for example: glauconitic, pyritic, feldspathic. In the sand and sandstone category, conventional divisions such as arkose, graywacke, etc., are, of course, acceptable, providing the scheme is properly identified. Clays, muds, silts, and sands containing $10 \%$ $30 \% \mathrm{CaCO}_{3}$ shall be called calcareous.

b) Volcanogenic sediments

Pyroclastic rocks are described according to the textural and compositional scheme of Wentworth and Williams (1932). The textural groups are:

Volcanic breccia $>32 \mathrm{~mm}$

Volcanic lapilli $<32 \mathrm{~mm}$

Volcanic ash (tuff, indurated) $<4 \mathrm{~mm}$

Compositionally, these pyroclastic rocks are described as vitric (glass), crystal or lithic.

c) Clastic sediments of volcanic provenance are described in the same fashion as the terrigenous sediments, noting the dominant composition of the volcanic grains where possible.

5) Special rock types-The definition and nomenclature of sediment and rock types not included in the system described above are left to the discretion of shipboard scientists with the recommendation that they adhere as closely as practical to conventional terminology.

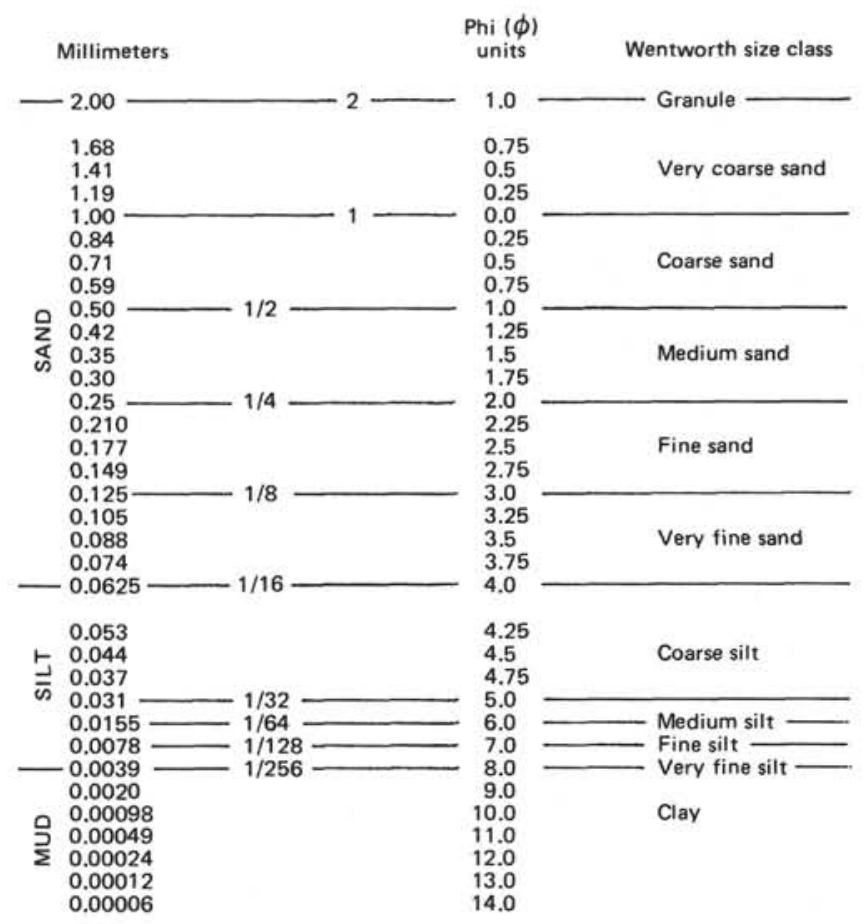

Figure 9. Grade scales for terrigenous sediments.

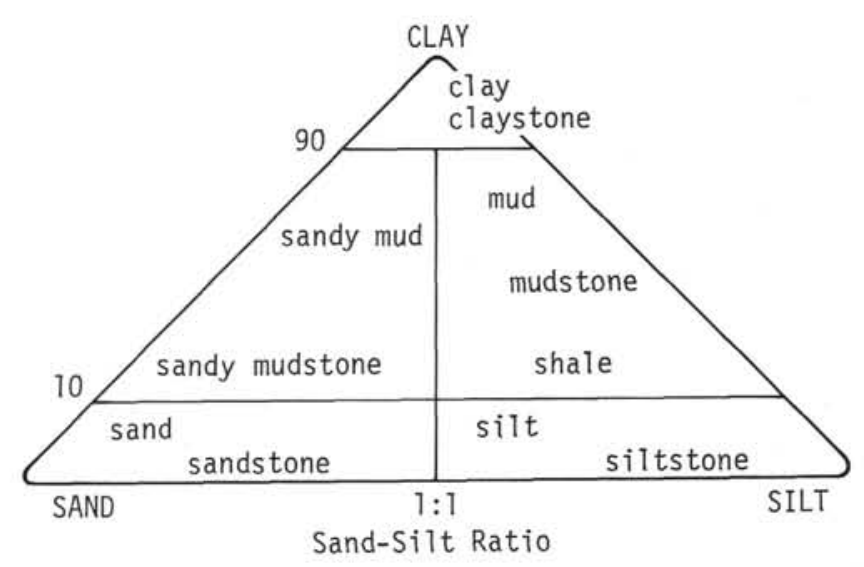

Figure 10. Class boundaries for terrigenous sediments.

In this category fall such rocks as:

Intrusive and extrusive igneous rocks;

Evaporites, halite, anhydrite, gypsum (as a rock), etc.;

Shallow water limestone (biostromal, biohermal, coquina, oolite, etc.);

Dolomite;

Gravels, conglomerates, breccias;

Metalliferous brown clays;

Concretions, barite, iron-manganese, phosphorite, pyrite, etc.;

Coal, asphalt, etc.;

and many others.

The mandatory graphic lithology column should be completed by shipboard staff with appropriate symbols for intervals containing special rock types. It is imperative that symbols and rock nomenclature be properly defined and described by shipboard staff. 